\title{
Taze tavuk etlerinde aktif ambalajlama uygulamaları
}

\author{
Özge Özer ${ }^{1}$ (), Farnaz Naserifar ${ }^{2}$ (), Özlem Kızılırmak Esmer³ (D) \\ 1,2,3 Ege Üniversitesi Gıda Mühendisliği Bölümü, Bornova, İzmir, Türkiye.
}

Geliş tarihi / Received: 23.11.2019, Kabul Tarihi / Accepted: 06.03.2020

\begin{abstract}
Özet: Tavuk eti yüksek protein ve nem içeriği nedeniyle hem mikrobiyal hem de biyokimyasal bozulmalara oldukça açık olmasından dolayı raf ömrü kısa olan bir gıdadır. Ayrıca gerek gıdanın doğası gerek işleme koşulları nedeniyle patojen mikroorganizmalarla kontamine olma ihtimali yüksektir. Bu açıdan taze tavuk etinin güvenilir bir şekilde üretimini arttırmak ve son tüketiciye ulaşana kadar israf olmasını önlemek amacıyla mikrobiyal güvenliğini sağlamak oldukça önemlidir. Taze tavuk etlerinde koruyucu katkı maddeleri ilavesi, ısıl işlem uygulamaları ve/veya dondurma vb. gıda muhafaza yöntemleri kullanılmamaktadır. Bu nedenle de üründe gerçekleşebilecek biyokimyasal değişimler ve mikrobiyal bozulmaları önlemek için ambalajlama teknolojilerinden yararlanılması işlenmiş gıda ürünlerine göre daha da önem kazanmaktadır. Yenilikçi ambalajlama teknolojileri ile taze tavuk etlerinin kalitesi arttırılıp raf ömrü uzatılabilir. Bu bağlamda aktif ambalajlama teknolojilerinden yararlanılabilir. Bu uygulamalarda ambalaj malzemesine ya da ambalaj ortamına eklenen antimikrobiyal ve antioksidan maddeler, $\mathrm{CO}_{2^{\prime}}$ etanol vs. gibi aktif maddelerin etkisiyle gıdanın özellikleri ambalajlandıktan sonra da iyi bir şekilde muhafaza edilebilmektedir. Son yıllarda taze tavuk etlerinin aktif ambalajlama teknolojisi ile ilgili olarak yapılan çalışmalarda; antimikrobiyal ya da antioksidan özelliklerde esansiyel yağlar ile doğal bitki ya da gıda sanayii atıklarından elde edilen ekstraktlar kullanılarak hazırlanan sentetik ve/veya biyobozunur polimerler kullanılmaya başlanmıştır. Bu teknoloji ile ambalajlanmış taze tavuk etlerinde bozulma yapan mikroorganizmaların üreme hızlarının yavaşlatıldığı, patojen mikroorganizmaların üremesinin engellendiği ve/veya lipid oksidasyon hızının azaltıldığına yönelik sonuçlar bulunmaktadır. Bu derlemede aktif ambalajlama uygulamalarının taze tavuk etlerinin kalitesi, güvenilirliği ve raf ömrü üzerine etkilerini araştıran bilimsel çalışmalar değerlendirilmiştir.
\end{abstract}

Anahtar kelimeler: Aktif Ambalajlama, Antimikrobiyal Ambalajlama, Antioksidan Ambalajlama, İnovatif Ambalajlama, Taze Tavuk Eti

\section{Active packaging applications in fresh chicken meat}

\begin{abstract}
Chicken meat is a food, with a short shelf life due to its high protein and moisture content, which is highly susceptible to both microbial and biochemical degradation. Furthermore, to increase the reliable production of fresh chicken meat and to ensure its microbial safety in order to prevent wasting until reaching the end consumer are very important due to the possibility of contamination with pathogenic microorganisms which are caused by the food nature and processing conditions. In fresh chicken meats, since food preservation methods like addition of preservatives, heat treatment applications and / or freezing etc. are not used; the use of packaging technologies to prevent biochemical changes and microbial deterioration in the product becomes more important than processed food products. With innovative packaging technologies, the quality of fresh chicken meats can be increased and the shelf life extended, thus ensuring better food safety. Active packaging technologies can be utilized in this context. For this purpose, by the action of active ingredients such as antimicrobial substances, antioxidant substances, $\mathrm{CO}_{2}$, ethanol, etc. added to the packaging material or packaging medium, the properties of the food can also be maintained well after packaging.

In recent years, in the studies on the active packaging technology of fresh chicken meat; synthetic / biodegradable polymers are started to be used which are prepared by using essential oils, extracts from natural plant or food industry wastes, with antimicrobial or antioxidant properties. For fresh chicken meats packed with this technology; there are results that the reproduction rate of the degrading microorganisms is slowed, the growth of pathogen microorganisms is inhibited and/or lipid oxidation rate is reduced. In this review, scientific studies investigating the effects of active packaging applications on the quality, safety and shelf life of fresh chicken meats were evaluated.
\end{abstract}

Key words: Active Packaging, Antimicrobial Packaging, Antioxidant Packaging, Fresh Chicken Meat, Innovative Packaging,

\section{Giriş}

Tavuk eti, özellikle yüksek protein oranından dolayı besin değeri yüksek, kırmızı ete göre nispeten daha ucuz ve bu özellikleri nedeniyle oldukça sık tüketilen bir gıda türüdür. Ancak yüksek protein ve nem oranından dolayı pek çok mikroorganizmanın geli- 
şimini teşvik etmesi nedeniyle hem mikrobiyal olarak hem de biyokimyasal olarak kolay bozulabilen ve bu nedenle raf ömrü kısa olan bir gıda maddesidir (Ghollasi-Mood ve ark. 2016). Kanatlı etlerinde bozulmaya neden olan baskın tür Pseudomonas türleridir. Bunun yanısıra Brochothrix thermosphacta, Laktik asit bakterileri, Enterobacteriaceae familyası Acinetobacter, Moraxella, Enterococcus türleri ve bazı mikroaerofilik mayaların da taze tavuk etlerinin bozulmasında önem taşıdığı bilinmektedir (Rouger ve ark. 2017; Şireli 2019). Bozulma yapan bakterilerin yanı sıra taze tavuk etlerinin mikrobiyal kontaminasyonunda insanlarda sindirim sistemi rahatsızlıklarına sebep olan Salmonella, Camplyobacter türleri ve Listeria monocytogenes gibi önemli patojenler de rol almaktadır (Rouger ve ark. 2017). Bundan dolayı taze tavuk etlerinin mikrobiyal kalitesi ve güvenilirliği, üretimi ve tüketimi artırmak için gıda sanayii açısından oldukça önemlidir. Raf ömrü sırasında bozulma yapan bakterilerin üremesi ve metabolik aktiviteleri sonucunda ürünlerin renk, koku, tat ve dokusal özelliklerindeki olumsuzluklar nedeniyle her yıl binlerce ton tavuk eti atık durumuna gelmekte ve önemli ekonomik kayıplar olmaktadır.

Taze tavuk etlerinin kısa raf ömründen dolayı hem gıda sanayi hem de bilim adamları bu tür ürünlerin raf ömrünü uzatmak, kalite özelliklerini muhafaza etmek için yeni teknolojiler üzerinde odaklanmışlardır. Bu bağlamda gerek gıda kalitesini ve gıda güvenilirliğini sağlamaya yönelik, gerekse de gıdanın raf ömrünü uzatmaya ve böylelikle gıdaların atık durumuna gelmesini önlemeye yönelik olarak inovatif ambalajlama teknolojileri oldukça önem arz etmektedir. Bu derleme çalışmasında; inovatif ambalajlama teknolojilerinden aktif ambalajlama uygulamalarının gerçekleştirilen bilimsel çalışmalar temelinde taze tavuk etlerinin kalitesi ve güvenilirliği açısından etkileri incelenmiştir.

\section{Aktif Ambalajlama Teknolojisi}

Ambalajlama teknolojisinin amacl; gıdayı oksijen, nem, ışık gibi dış faktörlerin etkisinden ve her türlü bulaşmadan koruyarak muhafaza etmektir (Vilela ve ark. 2018; Yıldırım ve ark. 2018). Aktif ambalajlama teknolojisinde ise ambalaj malzemesine ekstra özellikler kazandırılarak gıdanın kalitesini muhafaza etmek, gıda güvenilirliğini sağlamak, raf ömrünü uzatmak amaçlanmaktadır. Bu teknolojide ambalaj materyali, ambalaj ortamı ve gıda maddesi, ambalajın içinde gerçekleşen olayları kontrol altına alabilmek, bunlara tepki verebilmek ve değişen koşullara göre gıdanın muhafazasına ve kalitesini ko- rumaya yönelik istenen değişimleri gerçekleştirebilmek adına karşııklı etkileşim içinde bulunmaktadır (Singh ve ark., 2011; Vilela ve ark. 2018; Souza ve ark. 2019). Bu amaçla ambalaj malzemesine ya da ambalaj ortamına bazı aktif maddeler eklenmekte ve aktif maddeler "emici-tutucu" ya da "salıcı-yayıCı" sistemler olarak iki farklı prensiple çalışmaktadır. Gıdanın bozulmasına neden olan $\mathrm{CO}_{2}, \mathrm{O}_{2}$, etilen, nem, kötü aroma bileşenleri gibi maddeler ambalaj ortamından uzaklaştırılarak ya da antimikrobiyal ve antioksidan maddeler, $\mathrm{CO}_{2}$, etanol ambalaj ortamına eklenerek gıdanın özellikleri daha iyi muhafaza edilebilmektedir (Keokamnerd ve ark. 2008; Lorenzo ve ark. 2014; Majid ve ark. 2018).

Aktif ambalajlama teknolojisinde aktif maddeler, direkt ambalaj malzemesine eklenebildikleri gibi minik poşet şeklinde ya da etiket şeklinde ambalaj içerisine ayrı bir materyal olarak da eklenebilirler ya da içecek gibi gıdaların konulduğu şişelerde şişe kapağına da yerleştirilebilirler (Üçüncü, 2007; Kızılırmak Esmer ve Şahin, 2018).

\section{Taze Tavuk Etlerinde Antimikrobiyal ve Antioksidan Ambalajlama Uygulamaları}

Aktif ambalajlama teknolojileri içerisinde en fazla kullanım alanı bulmuş olan uygulamalar antimikrobiyal ve antioksidan ambalajlamadır. Antimikrobiyal ambalajlama teknolojisinde, gıdalarda mikrobiyal üremenin engellenmesi veya yavaşlatılması; antioksidan ambalajlama teknolojisinde ise oksijene duyarlı gıdaların oksidasyon stabilitesinin arttırıması ve böylece gıdanın oksidatif bozulmalardan korunması amaçlanmaktadır. Her iki ambalajlama teknolojisinde de aktif bileşenler ambalaj materyalinin yapısına veya ambalaj ortamına eklenmekte ya da ambalaj materyali aktif bileşenlerle kaplanmaktadır (Han 2000; Appendini ve Hotchkiss, 2002; Suppakul ve ark., 2003; Azlin-Hasim ve ark. 2015; Zhang ve ark. 2016). Bu anlamda en fazla uygulama alanı bulmuş olan gıda maddeleri ise taze et ürünleridir (Gibis ve Rieblinger 2011).

Antimikrobiyal ve antioksidan ambalajlama uygulamalarında, aktif maddenin ambalaj materyaline veya ambalaj içine eklenmesinin, katkı maddesinin gıdaya eklenmesine göre bazı avantajları bulunmaktadır (Khaneghah ve ark. 2018). Aktif ambalajlamada aktif maddelerin salımı yavaş ve kontrollü bir şekilde gerçekleşmekte, daha düşük konsantrasyonlarda koruyucu katkı maddesi kullanılabilmekte, püskürtme, karıştırma, daldırma gibi katkı maddesini gıdaya uygulama proseslerine gerek kalmamaktadır (Ahmed ve ark. 2017). Direkt gıda formülasyonuna 
eklenen antimikrobiyal ya da antioksidan özellikteki maddeler gıdanın lezzet, renk ya da viskozite gibi kalite özelliklerini olumsuz etkileyebilirken, bu teknoloji ile bu olumsuzlukların önüne geçilebilmektedir (Mastromatteo ve ark. 2010; Dicastillo ve ark. 2013; Tian ve ark. 2013).

Son yıllarda tüketicilerin daha doğal gıdalara olan talepleri doğrultusunda, tavuk etinde ürünün raf ömrünün uzatılması ya da güvenilirliğinin arttırılması amacıyla aktif ambalajlama teknolojilerinde de daha doğal bileşenlerin kullanılması üzerine araştırmalar yoğunlaşmaktadır (Azlin-Hasim ve ark. 2015). Özellikle son yıllarda, antimikrobiyal ya da antioksidan özellikte esansiyel yağların, doğal bitki ya da gıda sanayii atık ekstraktlarının kullanılarak hazırlandığı gerek sentetik gerekse biyobozunur polimerler ile ambalajlanmış taze tavuk etlerinde bozulma yapan mikroorganizmaların üreme hızlarının yavaşlatıldığı, patojen mikroorganizmaların üremesinin engellendiği ve/veya lipid oksidasyonu hızının yavaşlatıldığına yönelik sonuçlar bulunmaktadır.

Aktif ambalajlamada da kullanılan nano malzemeler, özellikle mekanik ve bariyer özellikleri zayıf olan biyobozunur ambalaj materyalinin bu olumsuz özelliklerini geliştirmek amacıyla kullanılan nano boyutlarda dolgu maddeleridir (Panea ve ark. 2014). Bazı çalışmalarda esansiyel yağlar nano malzemelerle kombine edilerek kullanılmıştır. Bu amaçla yapılan çalışmaların birinde taze kümes hayvanları etleri, \% 2 biberiye veya \% 2 zencefil esansiyel yağı içeren kitosan / montmorillonit (MMT) nanobiyokompozit filmlerle ambalajlanmıştır. MMT eklenmemiş kitosan filmlere kıyasla MMT eklenmiş kitosan filmlerin lipid oksidasyonunu yarı yarıya düşürme etkisi olduğu ve aerobik mezofilik bakteri ve toplam koliform sayısını \% 6-16 oranında azalttığı görülmüştür. Nanokil ilavesi, kitosan filmlerin bariyer özelliklerini geliştirmesi nedeniyle kitosan filmlerin antimikrobiyal ve antioksidan etkisini arttırmıştır. Ancak esansiyel yağların, kitosan/MMT nanobiyokompozit filmlere herhangi bir ekstra antimikrobiyal özellik sağlamadığı ve taze kanatlı etlerinin raf ömrünü arttırmada herhangi bir etkisinin olmadığı görülmüştür (Pires ve ark. 2018). Tek veya iki katlı olarak hazırlanan, \% 15 oranında üzüm çekirdeği ekstraktı (ÜÇE) ve/ veya \% 2 oranında nanoselüloz (NS) içeren kitosan ve/veya polikaprolakton filmlerin, tavuk göğsü filetosunun alt ve üst kısımlarına yerleştirildiği ve alçak yoğunluklu polietilenle ambalajlandığı bir çaIışmada, hazırlanan antimikrobiyal filmlerin; toplam aerobik mezofilik bakteri, toplam koliform bakteri ve lipid oksidasyonu üzerine etkisi incelenmiştir. ÜÇE'nın tavuk göğsü fileto örneklerindeki lipid ok- sidasyonunu ve mikrobiyal gelişmeyi engellemede NS içeren kitosan filmlerle birlikte kullanıldığında daha etkili olduğu ve NS'nin tavukgöğsü filetoları üzerine ÜÇE'nın salımını yavaşlattığı ve böylece 15 gün boyunca antioksidan aktivitenin sağlanabildiği belirlenmiştir (Söğüt ve Seydim 2019). Başka bir çaış̧mada, \% 50 tarçın esansiyel yağını antimikrobiyal etkili gümüş-bakır (Ag-Cu) (\% 4) nanoparçacıklarıyla beraber içeren ve sıkıştırma döküm yöntemiyle üretilen lineer alçak yoğunluklu polietilen veya polilaktikasit filmler üretilmiştir. Aktif özellikteki ambalaj malzemesiyle ambalajlanan patojen inoküle edilmiş taze tavuk etinin $4^{\circ} \mathrm{C}^{\prime}$ de 21 gün süreyle depolanması sırasında Salmonella typhimurium ve Campylobacter jejuni'nin üremesinin tamamen engellendiği ve Listeria monocytogenes'in ise üremesinin önemli ölçüde yavaşlatıldığı belirlenmiştir (Ahmed ve ark. 2018a, 2018b).

Başka bir çalışmada ise biyoaktif bileşenlerin etkinliklerini korumak amacıyla uygulanan yöntemlerden biri olan enkapsülasyon yöntemiyle çay ağacı yağı liposoma enkapsüle edilerek kitosandan elektroeğirme (elektrospinning) yöntemiyle aktif özellikte nanofilm üretilmiştir. Bu aktif özellikte nanofilmine ambalajlanan tavuk etindeki Salmonella typhimurium ve Salmonella enteritidis üremesi üzerindeki antibakteriyel aktivitesi değerlendirilmiş, enkapsule edilmiş çay ağacı yağı liposomunun Salmonella üzerinde yüksek antibakteriyel etki gösterdiği ve bu esnada duyusal özellikler üzerinde de herhangi bir olumsuz etkisinin olmadığı ve tavuk etinin raf ömrünü uzattığı görülmüştür (Cui ve ark. 2018). Elektroeğirme yönteminin kullanıldığı başka bir çalışmada ise gıdalar için doğal bir antimikrobiyal katkı maddesi olan $\varepsilon$-polilizin $(\varepsilon-P L)$ ve kitosan kullanılarak nanolif üretilmiş ve Salmonella typhimurium ve Salmonella enteritidis patojenleriyle inoküle edilmiş taze tavuk etleri bu malzeme ile ambalajlanmıştır. $4^{\circ} \mathrm{C}^{\prime}$ de 14 gün ve $25^{\circ} \mathrm{C}^{\prime}$ de 7 gün depolama süresince antimikrobiyal etki ve duyusal özellikler incelenmiştir. $\varepsilon$-polylysine içermeyen kontrol gruplarında depolama süresi sonunda çok daha yüksek mikroorganizma sayılarına ulaşılırken, $\varepsilon$-PL/kitosan filmde yaklaşık 3 logaritmik birimlik azalma olduğu tespit edilmiştir. Benzer sonuçlar $4^{\circ} \mathrm{C}$ depolama sıcaklığında da alınmıştır. Bu çalışma nanoliflerin gıda ambalajı olarak önemli ölçüde etkili antibakteriyel potansiyele sahip olduğunu ve ambalajlanmış gıdanın duyusal özelliklerini de daha iyi muhafaza ederek raf ömrünü artırabileceğini göstermiştir (Lin ve ark. 2018).

Dökme plak yönteminin uygulandığı bir çalışmada, fenolik bileşenler açısından zengin olan yer- 
fıstığı zarı ve pembe karabiber sanayi atıklarının ekstraktları sırasıyla \% 0.84 ve \% 1.90 oranında kullanılarak hazırlanmış kitosan filmlerle kemiksiz ve derisi alınmış tavuk baget eti ambalajlanmıştır. Lipid oksidasyonuna yönelik oksidatif stabiliteyi sağlamak açısından $4^{\circ} \mathrm{C}^{\prime}$ de 7 günlük depolama süresi boyunca her iki ekstraktın da, sektörde sentetik antioksidan olarak kullanılan bütillendirilmiş hidroksitoluen kadar etkili olduğu görülmüştür. Ayrıca mezofilik bakteri sayısında doğal antioksidan içermeyen kontrol grubuna göre bir farklılık görülmemesine rağmen psikrotrofik bakteri sayılarının aktif ambalajlama uygulamasında kontrol örneğine göre daha düşük olduğu belirlenmiştir (Serrano-León ve ark. 2018). Dökme plak yönteminin uygulandığı başka bir çalışmada ise farklı oranlarda selülozdan üretilen bir biyopolimer olan karboksimetil selüloz, biyobozunur film uygulamalarında oldukça iyi bir potansiyele sahip petrol türevli bir plastik olan polivinil alkol ve \% 1, 2, 3 konsantrasyonda karanfil esansiyel yağı kullanılarak hazırlanan filmlerle ambalajlanan tavuk kıymasının buzdolabı koşullarında 12 gün süreyle depolanması sonucunda; \% 3 oranında karanfil yağı içeren aktif filmle ambalajlanmış tavuk kıymasının raf ömrünün, karanfil yağı eklenmemiş kontrol numunesine kıyasla 4 günden 12 güne çıktığı tespit edilmiştir. Aktif filmlerle ambalajlanmış tavuk eti kıymasına inoküle edilen Staphylococcus aureus ve Bacillus cereus'un depolama süresi boyunca üremesinin azalarak 12 . günden itibaren tamamen inhibe edildiği gözlenmiştir (Muppalla ve ark. 2014). Karanfil esansiyel yağı kullanılan başka bir çalışmada ise, kromik asit ile modifiye edilen lineer alçak yoğunluklu polietilen film bu yağla kaplanarak, Salmonella typhimurium ve Listeria monocytogenes inokule edilmiş tavuk etinin ambalajlanmasında kullanılmıştır. $4^{\circ} \mathrm{C}^{\prime}$ de 21 gün süreyle depolama boyunca belirtilen patojenlere karşı etkin bir antimikrobiyal etki gözlenmiş ve depolama süresi boyunca üremenin azalarak 5. günden itibaren tamamen inhibe edildiği belirlenmiştir (Mulla ve ark. 2017). Dökme plak yönteminin uygulandığı başka bir çalışmada ise tavuk fileto örnekleri, polipropilen /etilen vinil alkol kopolimer tepsilerin orta kısmına, dökme plak yöntemiyle hazırlanmış farklı boyutlardaki kekik esansiyel yağının bileşeni olan karvakrol içeren kitosan/siklodekstrin antimikrobiyal filmler yerleştirilerek ambalajlanmıştır. $4^{\circ} \mathrm{C}^{\prime} \mathrm{de}$ 9 gün depolama sonucunda, toplam mezofilik bakteri, toplam psikrofilik bakteri, Pseudomonas türleri, Enterobacteriaceae, laktik asit bakterileri, maya ve mantarlara karşı tepsilere yerleştirilen aktif filmlerin yüzey alanıyla ve depolama süresiyle doğru orantılı olarak antimikrobiyal etki gösterdiği belirlenmiş ve en fazla yüzey alanına sahip filmin test edilen tüm mikroorganzimalar için yaklaşık olarak 1 logaritmik azalma sağladığı görülmüştür (Higueras ve ark. 2014). Aynı yöntemin kullanıldığı bir diğer çalışmada, \% 20 ve \% 50 oranında biberiye esansiyel yağı (BEY) içeren ve dökme plak yöntemiyle hazırlanmış selüloz asetat bazlı filmler polistiren tabaklar içerisine yerleştirilerek, dilimlenmiş tavuk göğsü ambalajlandığı bir çalışmada ise aktif özellikteki filmlerin toplam psikrotrof bakteri ve toplam koliform bakteri üzerindeki etkisi $2^{\circ} \mathrm{C}^{\prime}$ de 6 gün boyunca test edilmiştir. \% 20 BEY içeren filmler her iki mikroorganizmayı inhibe etmede herhangi bir etki göstermezken, \% 50 BEY içeren filmler psikrotrof bakterileri inhibe etmede herhangi bir etki göstermemiş ancak toplam koliform bakteri sayısında 2 logaritmik birim azalma sağlamıştır (De Melo ve ark. 2012).

Polietilen terefitalat (PET) filmlerle yapılan bir çalışmada ise, katman katman bir araya getirme yöntemiyle (layer-by-layer teknik) \% 1 siyah kimyon esansiyel yağı içeren aljinat ve kitosan kaplanmış aktif özellikteki PET filmler, köpük plastik tabakların ortasına yerleştirilerek tavuk gögüs etinin ambalajlanmasında kullanılmıştır. Bu filmlerin aktif özellikteki PET film içermeyen kontrol örneğine göre $4^{\circ} \mathrm{C}$ 'de 5 gün depolama süresi boyunca mezofilik ve psikrotrofik bakteri üremesini düşük oranda da olsa geciktirdiği ve daha iyi sonuçlar elde edebilmek için daha yüksek esansiyel yağ konsantrasyonlarının çalışılması gerektiği belirtilmiştir (Konuk Takma ve Korel 2018). Alçak yoğunluklu polietilen filmlerin kullanıldığı başka bir çalışmada ise filmlerin yüzeyine biberiye ekstraktının kaplanmasıyla elde edilen aktif filmle ambalajlanmış ve $5^{\circ} \mathrm{C}^{\prime}$ de depolanmış tavuk köftesinde lipid oksidasyonunun 25 güne kadar geciktiği ve bu sayede raf ömrünün uzatıldığı belirlenmiştir (Bolumar ve ark. 2011). Lactococcus lactis'in fermentasyonuyla elde edilen bir bakteriyosin olan nisin veya kitosan ilave edilerek plastik işleme yöntemlerinden biri olan ekstrüzyon yöntemiyle elde edilen alçak yoğunluklu polietilen ambalajların, 6 gün boyunca $5^{\circ} \mathrm{C}$ 'de depolanan tavuk bagetlerin fizikokimyasal ve mikrobiyal kalitesi üzerindeki etkilerinin incelendiği bir çalışmada, kitosanın aerobik mezofilik bakteri, toplam koliform ve küf ve maya üzerinde en etkili antimikrobiyal ajan olduğu, nisinin de aynı mikroorganizmalar üzerinde kitosana kıyasla daha düşük de olsa antimikrobiyal etki gösterdiği görülmüştür. Bunun yanısıra lipid oksidasyonu da nisin veya kitosan içermeyen kontrol örneklerine göre önemli ölçüde engellenmiştir. Yapılan bu çalışma kitosan ve nisin içeren aktif ambalajların tavuk bagetlerinin ambalajlanmasında gıda kalitesi ve güvenilirliğini arttırdığını 
ve ambalajlama için uygun olduğunu göstermiştir (Soysal ve ark. 2015).

\section{Sonuç}

Yapılan çalışmalar göstermektedir ki inovatif ambalajlama uygulamaları taze tavuk eti kalitesinin ve güvenilirliğinin sağlanmasında oldukça etkili olabilecek uygulamalardır. Çalışmaların bir bölümünde aktif ambalaj üretiminde ekstrüzyon gibi endüstriyel ambalaj üretim yöntemleri uygulanmıştır. Aktif özellikte bu filmlerin endüstriyel olarak kullanılabilmesi için endüstriyel ambalaj üretim yöntemlerine uyarlanması gerekmektedir. Özellikle doğal bileşenler söz konusu olduğunda ambalaj üretim yöntemleriyle bu bileşenlerin ambalaj malzemesinde ne kadar etkin bir oranda kalabildiği önemlidir. Bu nedenle enkapsülasyon tekniği gibi biyoaktif maddelerin ko- runmasında etkili olan yöntemler önem kazanmaktadır. Ayrıca esansiyel yağlar keskin aromalı bileşenler olduğu için çok yüksek konsantrasyonda uygulanamamaktadırlar. Bu nedenle bu tür çalışmalarda aktif bileşen konsantrasyonlarının, ürünün özelliklerini korumadaki etkisi ve ürünün duyusal özellikleri üzerine etkisinin birlikte çalışılarak optimize edilmesi gerektiği düşünülmektedir.

Bunun yanı sıra üretim maliyetleri yeni bir teknolojinin uyarlanmasında kritik bir öneme sahip olduğundan maliyet hesaplarının yapılması da göz ardı edilmemesi gereken bir durumdur. Ancak aktif maddelerin sağlayacağı faydayla kıyaslandığında yaratacağı maliyet farklılığının çok önemli olmayacağı düşünülmektedir. Tablo 1'de antimikrobiyal doğal bileşenleri içeren ve ticari olarak mevcut bazı antimikrobiyal ambalaj örnekleri görülmektedir.

Tablo 1. Doğal bileşenleri içeren ve ticari olarak mevcut bazı antimikrobiyal ambalajlama örnekleri (Ahmed ve ark. 2017; Fang ve ark. 2017)

\begin{tabular}{|c|c|c|c|}
\hline Ticari İsmi & Üretici Firma & Aktif Bileşen & Kullanım Şekli \\
\hline Wasaouro sheets ${ }^{\mathrm{TM}}$ & $\begin{array}{l}\text { Mitsubishi-Kagaku Foods Co., } \\
\text { Japan }\end{array}$ & Alil izotiyosiyanat & $\begin{array}{l}\text { Antifungal, antibakteriyel filmler } \\
\text { ve etiketler }\end{array}$ \\
\hline Wasapower ${ }^{\mathrm{TM}}$ & Sekisui Plastics Co., Ltd., Japan & $\begin{array}{l}\text { Siklodekstrin içinde enkapsüle } \\
\text { edilmiş wasabi özütü }\end{array}$ & Kaplı PEF (Polietilen furanat) \\
\hline WasaOuro & Lintec Co., Japan & Alil izotiyosiyanat & Levhalar \\
\hline Bioka ${ }^{\mathrm{TM}}$ & Bioka Ltd., Finland & Glikoz oksidaz & Poşet \\
\hline
\end{tabular}

\section{Kaynaklar}

1. Ahmed I, Lin H, Zou L, Brody AL, Li Z. (2017). A comprehensive review on the application of active packaging technologies to muscle foods. Food Control. 82, 163-178. https://doi.org/10.1016/j.foodcont.2017.06.009

2. Ahmed J, Arfat YA, Bher A, Mulla M, Jacob H. (2018b). Active chicken meat packaging based on polylactide films and bimetallic ag-cu nanoparticles and essential oil. Journal of Food Science. https://doi.org/10.1111/1750-3841.14121

3. Ahmed J, Mulla M, Ali Arfat Y, Bher A, Jacob H. (2018a). Compression molded LLDPE films loaded with bimetallic $(\mathrm{Ag}-\mathrm{Cu})$ nanoparticles and cinnamon essential oil for chicken meat packaging applications. LWT - Food Science and Technology. 93, 329-338. https://doi.org/10.1016/j.lwt.2018.03.051

4. Appendini P, Hotchkiss JH. (2002). Review of antimicrobial food packaging. Innovative Food Science and Emerging Technologies. 3(2), 113-126. https://doi.org/10.1016/S14668564(02)00012-7

5. Azlin-Hasim S, Cruz-Romero MC, Morris MA, Cummins E, Kerry JP. (2015). Effects of a combination of antimicrobial silver low density polyethylene nanocomposite films and modified atmosphere packaging on the shelf life of chicken breast fillets. Food Packaging and Shelf Life. 4, 26-35. https://doi.org/10.1016/j.fpsl.2015.03.003

6. Bolumar T, Andersen ML, Orlien V. (2011). Antioxidant active packaging for chicken meat processed by high pressure treatment. Food Chemistry. 129 (4), 1406-1412. http://dx.doi. org/10.1016/j.foodchem.2011.05.082
7. Cui H, Bai M, Li C, Liub R, Lin L. (2018). Fabrication of chitosan nanofibers containing tea tree oil liposomes against Salmonella spp. in chicken. LWT-Food Science and Technology. 96, 671-678. https://doi.org/10.1016/j.lwt.2018.06.026

8. de Melo AAM, Geraldine RM, Silveira MFA, Torres MCL, E Rezende CSM. (2012). Microbiological quality and other characteristics of refrigerated chicken meat in contact with cellulose acetate-based film incorporated with rosemary essential oil. Brazilian Journal of Microbiology. 43 (4), 1419-1427. doi: 10.1590/S1517-838220120004000025

9. Fang Z, Zhao Y, Warner RD, Johnson SK. (2017). Active and intelligent packaging in meat industry. Trends in Food Science \& Technology. 61 (2), 60-71. https://doi.org/10.1016/j. tifs.2017.01.002

10. Ghollasi-Mood F, Mohsenzadeh M, Housaindokht MR, Varidi M. (2016). Microbial and chemical spoilage of chicken meat during storage at isothermal and fluctuation temperature under aerobic conditions. Iranian journal of veterinary science and technology. 8 (1). doi: 10.22067/veterinary.v8i1.54563

11. Gibis, D, Rieblingera K. (2011). Oxygen scavenging films for food application. Procedia Food Science. 1, 229 - 234. https:// doi.org/10.1016/j.profoo.2011.09.036

12. Han JH. (2000). Antimicrobial food packaging. Food Technology. 54 (3), 56-65. DOI: 10.1533/9781855737020.1.50

13. Higueras L, López-Carballo G, Hernández-Muñoz P, Catalá R, Gavara R. (2014). Antimicrobial packaging of chicken fillets based on the release of carvacrol from chitosan/cyclodextrin 
film. International Journal of Food Microbiology. 188, 53-59. http://dx.doi.org/10.1016/j.ijfoodmicro.2014.07.018

14. Keokamnerd T, Acton JC, Han IY, Dawson PL. (2008). Effect of Commercial Rosemary Oleoresin Preparations on Ground Chicken Thigh Meat Quality Packaged in a High-Oxygen Atmosphere. Poultry Science. 87, 170-179. https://doi. org/10.3382/ps.2007-00066

15. Khaneghaha AM, Hashemib SMB, Limboc S. (2018). Antimicrobial agents and packaging systems in antimicrobial active food packaging: An overviewof approaches and interactions. Food and Bioproducts Processing. 111, 1-19. https://doi.org/10.1016/j.fbp.2018.05.001

16. Kızılırmak Esmer Ö, Şahin B. (2018). Active packaging applied to dairy products. Conto F, Del Nobile DA, Faccia M, Zambrini AV, Conte A. Eds. Advances in Dairy products. John Wiley and Sons Ltd. UK,. p. 356-377.

17. Konuk Takma D, Korel F. (2018). Active packaging films as a carrier of black cumin essential oil: Development and effect on quality and shelf-life of chicken breast meat. Food Packaging and Shelf Life. https://doi.org/10.1016/j.fpsl.2018.11.002

18. Lin L, Liao X, Surendhiran D, Cui H. (2018). Preparation of $\varepsilon$-polylysine/chitosan nanofibers for food packaging against Salmonella on chicken. Food Packaging and Shelf Life. 17, 134-141. https://doi.org/10.1016/j.fpsl.2018.06.013

19. López de Dicastillo C, Castro-López MDM, López-Vilariño JM, González-Rodríguez MV. (2013). Immobilization of green tea extract on polypropylene films to control the antioxidant activity in food packaging. Food Research International. 53 (1), 522-528. https://doi.org/10.1016/j.foodres.2013.05.022

20. Lorenzo JM, Sineiro J, Amado IR, Franco D. (2014). Influence of natural extracts on the shelf life of modified atmosphere-packaged pork patties. Meat Science. 96, 526-534. https://doi. org/10.1016/j.meatsci.2013.08.007

21. Majid I, Nayik GA, Dar SM, Nanda V. (2018). Novel food packaging technologies: Innovations and future prospective. Journal of the Saudi Society of Agricultural Sciences. 17, 454462. http://dx.doi.org/10.1016/j.jssas.2016.11.003

22. Mastromatteo M, Mastromatteo M, Conte A, Del Nobile MA. (2010). Advances in controlled release devices for food packaging applications. Trends in Food Science and Technology. 21 (12), 591-598. https://doi.org/10.1016/j.tifs.2010.07.010

23. Mulla M, Ahmed J, Al-Attar $H$, Castro-Aguirre E, Arfat YA. (2017). Antimicrobial efficacy of clove essential oil infused into chemically modified LLDPE film for chicken meat packaging. Food Control. 73 (part B), 663-671. http://dx.doi.org/10.1016/j.foodcont.2016.09.018

24. Muppalla SHR, Kanatt SR, Chawla SP, Sharma A. (2014). Carboxymethyl cellulose-polyvinyl alcohol films with clove oil for active packaging of ground chicken meat. ScienceDirect. 2 (2), 51-58. http://dx.doi.org/10.1016/j.fpsl.2014.07.002

25. Panea B, Ripoll G, González J, Fernández-Cuello A, Albertí P. (2014). Effect of nanocomposite packaging containing different proportions of $\mathrm{ZnO}$ and $\mathrm{Ag}$ on chicken breast meat quality. Journal of Food Engineering. 123, 104-112. https://doi. org/10.1016/j.jfoodeng.2013.09.029

26. Pires JRA, Souza VGL, Fernando AL. (2018). Chitosan/montmorillonite bionanocomposites incorporated with rosemary and ginger essential oil as packaging for fresh poultry meat.
Food Packaging and Shelf Life. 17, 142-149. https://doi.org/10.1016/j.fpsl.2018.06.011

27. Rouger A, Tresse O, Zagorec M. (2017). Bacterial Contaminants of Poultry Meat: Sources, Species, and Dynamics. Microorganisms. 5 (50). doi:10.3390/microorganisms5030050

28. Serrano-León JS, Bergamaschi KB, Yoshida CMP, Saldaña $E$, Selani MM. (2018). Chitosan active films containing agro-industrial residue extracts for shelf life extension of chicken restructured product. Food Research International. 108, 93100. https://doi.org/10.1016/j.foodres.2018.03.031

29. Singh P, Wani A. A, Saengerlaub S. (2011). Active packaging of food products: Recent trends. Nutrition and Food Science 41 (4), 249-260. https://doi.org/10.1108/00346651111151384

30. Sireli T. Kanatlı etlerinde bozulma. Erişim adresi: http://www. sagliklitavuk.org/assets/userfiles/files/uzmanlardan/Kanatli_Etlerde_Bozulma.pdf, Erişim Tarihi: 14 Ocak 2019

31. Souza VGL, Pires JRA, Vieira ET, Coelhoso IM, Duarte MP, Fernando AL. (2019). Activity of chitosan-montmorillonite bionanocomposites incorporated with rosemary essential oil: From in vitro assays to application in fresh poultry meat. Food Hydrocolloids. 89, 241-252. https://doi.org/10.1016/j. foodhyd.2018.10.049f

32. Soysal Ç, Bozkurt H, Dirican E, Güçlü M, Bozhüyük ED. (2015). Effect of antimicrobial packaging on physicochemical and microbial quality of chicken drumsticks. Food Control. 54, 294-299. http://dx.doi.org/10.1016/j.foodcont.2015.02.009

33. Söğüt E, Seydim AC. (2019). The effects of chitosan- and polycaprolactone-based bilayer films incorporated with grape seed extract and nanocellulose on the quality of chicken breast fillets. LWT - Food Science and Technology. 101, 799-805. https://doi.org/10.1016/j.lwt.2018.11.097

34. Suppakul P, Miltz J, Sonneveld K, Bigger SW. (2003). Active packaging technologies with an emphasis on antimicrobial packaging and its applications. Journal of Food Science 68 (2), 408-420. https://doi.org/10.1111/j.1365-2621.2003. tb05687.x

35. Tian F, Decker EA, Goddard JM. (2013). Controlling lipid oxidation via a biomimetic iron chelating active packaging material. Journal of Agricultural and Food Chemistry. 61 (50), 12397-12404. doi: 10.1021/jf4041832

36. Vilela C, Kurek M, Hayouka Z, Rocker B, Yildirim S, Antunes MDC, Nilsen-Nygaard J, Pettersen MK, Freire CSR. (2018). A concise guide to active agents for active food packaging. Trends in Food Science \& Technology. 80, 212-222. https://doi. org/10.1016/j.tifs.2018.08.006

37. Üçüncü M, eds.. (2007). Gıda Ambalajlama Teknolojisi. 2.Baskı. Meta Basım Matbaacılık Hizmetleri. İzmir. Pp.809-817.

38. Yildirim S, Röcker B, Pettersen MK, Nilsen-Nygaard J, Ayhan Z, Rutkaite R, Radusin T, Suminska P, Marcos B, Coma V. (2018). Active Packaging Applications for Food. Comprehensive Reviewsin Food Science and Food Safety. 17, 165-199. doi: 10.1111/1541-4337.12322

39. Zhang H, Wu J, Guo X. (2016). Effects of antimicrobial and antioxidant activities of spice extracts on raw chicken meat quality. Food Science and Human Wellness. 5, 39-48. https:// doi.org/10.1016/j.fshw.2015.11.003 